\title{
X-linked immunodeficiency with magnesium defect, Epstein-Barr virus infection and neoplasia
}

INSERM

\section{Source}

INSERM. (1999). Orphanet: an online rare disease and orphan drug data base. $\underline{X \text {-linked }}$ immunodeficiency with magnesium defect, Epstein-Barr virus infection and neoplasia. ORPHA:317476

X-linked immunodeficiency with magnesium defect, Epstein-Barr virus infection and neoplasia is a rare combined $\mathrm{T}$ and $\mathrm{B}$ cell immunodeficiency characterized by recurrent sinopulmonary and viral infections, persistent elevated Epstein-Barr virus (EBV) viremia and increased susceptibility to EBV-associated B-cell lymphoproliferative disorders. Immunological analyses show normal lymphocyte count or mild to moderate lymphopenia, inverted CD4:CD8 T-cell ratio and hypogammag lobulinemias. 